\title{
Biomarkers in Chronic Obstructive Pulmonary Disease: Emerging Roles of Eosinophils and Procalcitonin
}

\author{
Pradeesh Sivapalan $^{\mathrm{a}} \quad$ Jens-Ulrik Jensen ${ }^{\mathrm{a}} \mathrm{b}$ \\ aDepartment of Internal Medicine, Respiratory Medicine Section, Herlev and Gentofte Hospital, \\ University of Copenhagen, Hellerup, Denmark; ${ }^{\text {b}}$ Department of Clinical Medicine, Faculty of Health Sciences, \\ University of Copenhagen, Copenhagen, Denmark
}

\section{Keywords}

Biomarker · Blood eosinophils · Procalcitonin

\begin{abstract}
Antibiotics can improve the prognosis in patients with exacerbation of chronic obstructive pulmonary disease. However, the overuse of antibiotics can carry serious adverse effects for patients (gastrointestinal infections) and for society (bacterial resistance). Likewise, systemic corticosteroids may also help these patients, but also carries severe adverse effects like osteoporosis, muscle loss, and diabetes, in many patients. Whenever safe methods exist to reduce these two treatment modalities, they should be implemented. The blood biomarkers procalcitonin and the fraction of leukocytes known as eosinophil granulocytes have been proven in randomized controlled trials (RCTs), to effectively, significantly, and substantially assist in reducing the use of these two potent, yet toxic medication types. In this review, the background and main clinical results are discussed, explaining the rationale for biomarker-guided clinical decisions. Also, the main expected effects, their sizes, and importantly the limitations to such a strategy are described. Clinical evidence is prioritized with main weight on RCTs and meta-
\end{abstract}

karger@karger.com www.karger.com/jin

Karger!"

BOPEN ACCESS
(C) 2021 The Author(s)

Published by S. Karger AG, Basel

This is an Open Access article licensed under the Creative Commons Attribution-NonCommercial-4.0 International License (CC BY-NC) (http://www.karger.com/Services/OpenAccessLicense), applicable to the online version of the article only. Usage and distribution for commercial purposes requires written permission. analyses of these and regarding outcomes, and focus is set on the safety of such a biomarker-guided strategy, as well as the effects on medicine reduction. In an epoch of increasing demands to physicians from patients and politicians to cure and reduce symptoms, the Hippocratic phrase of "primum non nocere" or "first, do no harm" seems more than ever of contemporary importance.

(C) 2021 The Author(s)

Published by S. Karger AG, Basel

\section{Introduction}

Biomarkers of infection and inflammation have been used for decades in patients with lower respiratory tract infections and flares of inflammatory conditions [1-3]. Exacerbations in chronic obstructive pulmonary disease (COPD) are defined in several ways, although many clinicians and researchers use the classic Anthonisen criteria (increased dyspnea, increased sputum volumes, discolored sputum, and a therapeutic response). Such criteria can lead to the antibiotic and corticosteroid overuse, since they do not necessarily differentiate which patients are in need of such treatments, and in case of doubt, treatment will often be initiated, to avoid undertreating. 
For patients with COPD exacerbations, a potentially deadly condition, often requiring hospital admission, the usual biomarkers like the white blood cell count and Creactive protein seem not to be quite sufficient, when the clinician needs to decide whether to treat with antibiotics and systemic corticosteroids. These common biomarkers are not very sensitive and might be elevated for various reasons, even during stable periods due to systemic inflammation [4], and a low positive predictive value may cause unnecessary use of antibiotics [5]. This is far from satisfactory, since such treatments carry significant risks for the patient, such as serious gastrointestinal infections with Clostridium difficile, superinfections with resistant bacteria, muscle wasting, diabetes mellitus, and osteoporosis.

This review does not attempt to mention all candidate biomarkers for use in COPD patients, rather, the aim is to describe the clinical utility of two biomarkers, blood eosinophils and procalcitonin (PCT), that have been extensively investigated to assist in reducing corticosteroids in patients with severe COPD exacerbations and likewise to reduce unnecessary use of antibiotics. The reader will be able to (i) make a decision of whether there is sufficient evidence to support use of one or both of these biomarkers in his/her own setting, (ii) if decision to use them is made, then propose an evidence-based algorithm for the most effective way to use them.

Much is known about the concrete use of these biomarkers and what should be expected or not expected when using these biomarkers, how to interpret them, and how to implement them. The precise use of them has, however, only been implemented in few hospitals worldwide. Acute exacerbations of COPD may have distinct causes and can be viral, bacterial, or caused by eosinophilic inflammation, each with distinct treatment needs [6]. Due to diagnostic difficulty in distinguishing virally triggered acute exacerbations of COPD from those driven by bacterial infection, there is a potential for unnecessary use of antibiotics in this group of patients. The overuse of antibiotics for respiratory infections is an important driver of multidrug resistance. Therefore, it is imperative to develop effective diagnostic tools to guide both corticosteroid and antibiotic treatment in lung patients and in patients with respiratory infections [6].

\section{Eosinophilic Inflammation}

COPD exacerbation was initially thought to be mediated primarily by neutrophil-mediated inflammation, while eosinophilic inflammation is thought to be more characteristic in asthma rather than COPD. However, a subset of $20-40 \%$ of COPD patients displays eosinophilic airway inflammation, even when carefully excluding patients with possible asthma [7]. Eosinophils are key inflammatory and immune effector cells. Under normal conditions eosinophils are dormant in the blood, but upon exposure to pro-inflammatory cytokines (interleukin [IL]-3, IL-5 IL-6, and granulocyte-macrophage colony-stimulating factor) they activate and migrate to inflamed tissue [8]. Monoclonal antibodies targeting IL-5, the main cytokine involved in the activation of eosinophils, is known to reduce exacerbations of eosinophilic asthma effectively [9]. However, in eosinophil COPD, the effect of anti-IL-5 is still disputed [10], although many researchers have commented on the lack of eosinophilia as an inclusion criterion in these studies and claimed that blocking an eosinophil pathway makes less sense in patients without activation of such a pathway. Corticosteroids are unlike anti-IL drugs, commonly used for regular treatment of COPD, being particularly beneficial in patients with asthmatic or inflammatory features and comorbidities (such as asthma-COPD overlap syndrome) [11-13]. In healthy persons, eosinophils usually are not found in the lungs, and their presence in the lungs is indicative of an abnormal inflammatory reaction [14]. Eosinophils are typically quantified as a percentage of total leukocyte amounts or as absolute numbers (cells/ $\mu \mathrm{L}$ ). Both measurements have been shown to be in concordance with each other $[7,15]$. Blood eosinophil counts have also been shown to be in concordance with sputum eosinophil counts, and are therefore often used as a proxy for eosinophilic lung inflammation [8]. Eosinophilic inflammation can be present both during exacerbations and stable COPD [7]. Numerous studies have demonstrated associations between blood eosinophil counts and relevant clinical COPD outcomes. Most of the studies did find an association with higher blood eosinophils (eosinophilic COPD phenotype) and worse clinical outcomes in terms of increased risk of readmissions, longer hospital stays, and future exacerbations [16-20]. However, the association is not fully clarified.

\section{Inhaled Corticosteroid Use and the Blood Eosinophil Count}

According to previous guidelines, patients with moderate to very severe COPD should be treated with inhaled corticosteroids (ICS) [21]. However, the use of ICS in COPD patients has been shown to have a variable effect, which needs to be weighed against the side effects of the treatment such as increased incidence of pneumonia, diabetes [22], osteoporosis, and cataracts [23, 24]. Until re-
Sivapalan/Jensen 


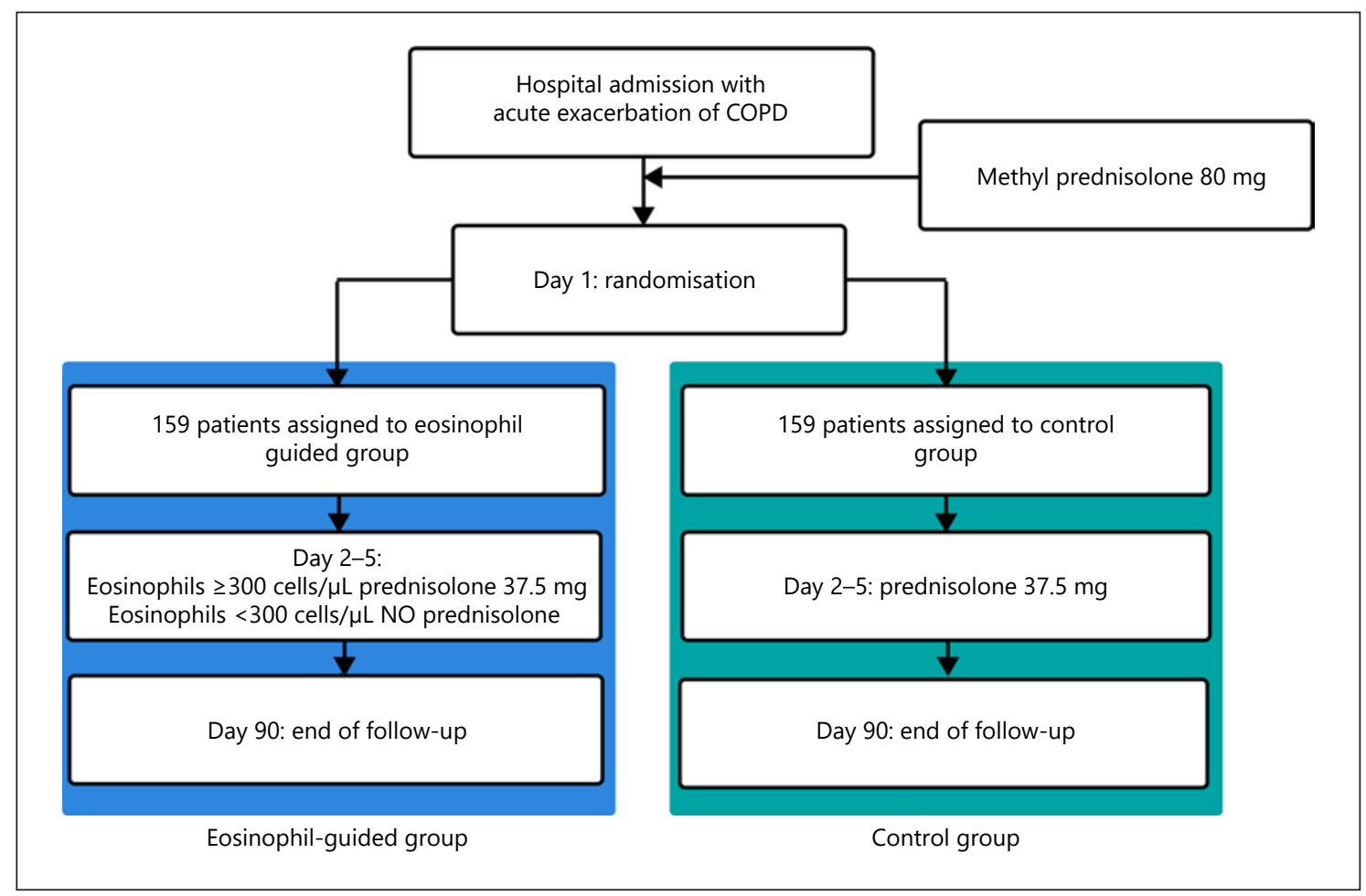

Fig. 1. Treatment algorithm from the CORTICO-COP trial [42].

cently, no serum biomarkers had a demonstrated association with COPD treatment response. In 2007, randomized controlled trials (RCTs) showed reduction in COPD exacerbation in patients with a sputum eosinophil count $>3 \%$ treated with ICS. Subsequently, peripheral blood eosinophils have been extensively studied and seem to be able to better predict the effect of ICS [25]. Several post hoc analyses looking at the benefits of ICS/LABA in comparison to LABA have shown a continuous relation between ICS response and eosinophil counts [15, 26, 27]. Other studies have grouped patients into discrete groups based on blood eosinophils and leading to similar conclusions that higher blood eosinophil levels increase the likelihood of ICS treatment benefit [28-30]. This is reflected in recent GOLD recommendations, that specify that eosinophil counts should be considered when deciding whether to administer ICS. The newest GOLD guidelines recommend ICS usage in patients with blood eosinophils $\geq 300$ cells $/ \mu \mathrm{L}$, and in patients with blood eosinophils $>100$ cells $/ \mu \mathrm{L}$, and persistent exacerbations while on bronchodilators [31]. Recently, the European Respiratory Society published a guideline for withdrawal of ICS based on the blood eosinophil count. This guideline recommends ICS withdrawal in patients with a blood eosinophil count $<300$ cells $/ \mu \mathrm{L}$ and no frequent exacerbations [32]. All these recommendations are, however, based on post hoc studies and currently, no RCTs have tested this algorithm. At this current time, there is one multicenter RCT seeking to validate these findings (NCT04481555), with planned readouts by 2025 .

\section{Systemic Corticosteroids and the Blood Eosinophil Count}

Unlike stable COPD, acute exacerbations are commonly treated with orally administered systemic corticosteroids such as prednisolone [21]. Systemic corticosteroids are used to improve recovery from symptoms, but they do not improve long-term decline in lung function, future exacerbations after the first month, and the length of stay in intensive care units or mortality [33]. The criteria used to define COPD exacerbations (an acute worsening of respiratory symptoms that result in additional therapy) are broad, and this may lead to the overuse of corticosteroids [31]. The overuse of systemic corticosteroids is associated with increased risk of osteoporotic fractures, cataracts, infections [34], and venous thromboembolism $[35,36]$. To reduce the usage of systemic corticosteroids, it has been proposed to use blood eosinophil counts to 


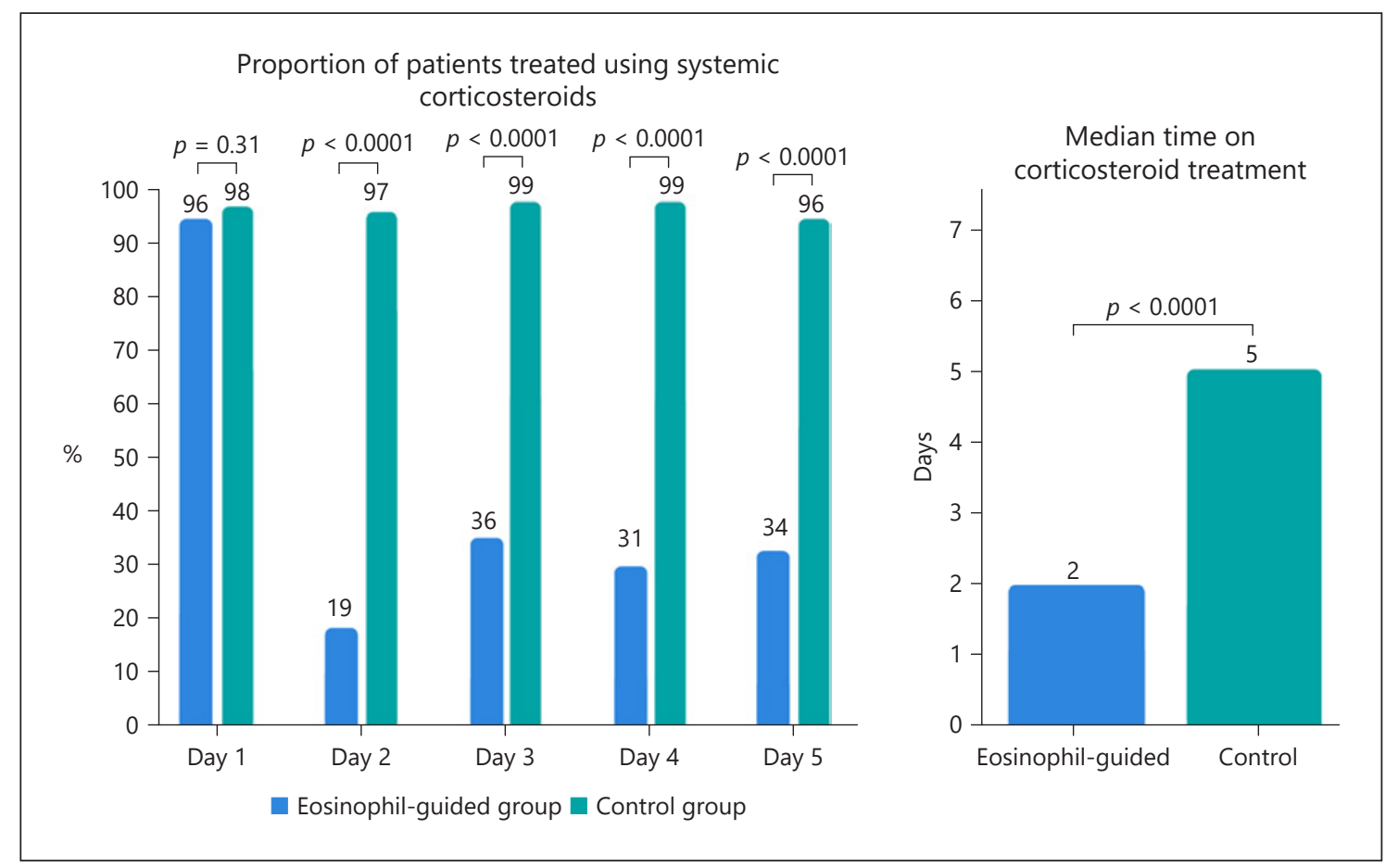

Fig. 2. Fraction of patients on systemic corticosteroid treatment and the median treatment length in the CORTICO-COP trial [42].

guide corticosteroid treatment. One RCT used blood eosinophils to categorize patients as having eosinophilic or noneosinophilic exacerbations and found noninferiority when treating noneosinophilic exacerbations with placebo rather than systemic corticosteroids. Notably, there was a reduction of $49 \%$ in the total corticosteroid prescription for the eosinophil-guided group $(p<0.001)$ [37]. Similarly, other studies have shown better corticosteroid response in COPD patients with higher eosinophil counts compared to patients with a lower blood eosinophil count [38-40]. The randomized noninferiority CORTICO-COP trial found that daily eosinophil counts could be used to guide treatment to reduce corticosteroid usage in hospitalized patients with COPD exacerbation using the algorithm shown in Figure 1. This led to a reduction in median corticosteroid treatment duration from 5 days to 2 days with approximately two-thirds of the eosinophil-guided patients being off corticosteroids on any given day throughout the study except on day 1 (shown in Fig. 2). This treatment algorithm was shown not to affect days alive and out of hospital within 14 days after recruitment or a 30-day all-cause mortality rate. There were documented fewer side effects in terms of fewer patients with hyperglycemia and fewer patients with worsening of diabetes in patients with preexisting diabetes in the eosinophil-guided corticosteroid group [41]. These analyses indicate that the blood eosinophil count could potentially be used as a biomarker to guide corticosteroid therapy for exacerbations and may help to avoid unnecessary exposure to systemic corticosteroids. In Table 1, some of the key trials of eosinophil-guided corticosteroid therapy are noted with the main characteristics and results.

\section{PCT Biology}

PCT is a 114 amino acid, $12.6 \mathrm{kDa}$ polypeptide prohormone of calcitonin [42]. Calcitonin is produced in the neuroendocrine medullary C-cells of the thyroid, which is embryologically derived from the neural crest [43]. PCT produced in the C-cells undergoes posttranslational processing, to form the bioactive calcitonin hormone of 32 amino acids. In animal studies, PCT has been isolated in the tissue from the adrenal gland, spleen, brain, liver, pancreas, colon, lung, fat tissue, spinal cord, testes, and stomach [44]. In bacterial sepsis, the mRNA of the calcitonin (CALC)-1 gene is upregulated more uniformly than the mRNA of other inflammatory cytokines, such as tumor necrosis factor- $\alpha$, IL-1 $\beta$, and IL-6 [45]. Mature calcitonin blood levels do not increase significantly during sepsis. The explanation for this has been proposed as a 
Table 1. Reduction in corticosteroid exposure in RCTs with blood eosinophil count-controlled algorithms

\begin{tabular}{llcllll}
\hline Study type and author & $\begin{array}{l}\text { Patient } \\
\text { group }\end{array}$ & $N$ & Primary outcome & $\begin{array}{l}\text { Reduction in antibiotic } \\
\text { exposure PCT arm } \\
\text { versus control }\end{array}$ & Strengths/weaknesses & Conclusion \\
\hline RCT, Bafadhel et al. [37] & AECOPD & 109 & $\begin{array}{l}\text { Noninferiority in the } \\
\text { health status score and } \\
\text { treatment failure }\end{array}$ & $\begin{array}{l}\text { Reduced by 49\% } \\
\text { (no apparent risk) }\end{array}$ & $\begin{array}{l}\text { Treatment based on } \\
\text { single exacerbation } \\
\text { blood eosinophil count }\end{array}$ & $\begin{array}{l}\text { Successful reduction of } \\
\text { corticosteroid exposure }\end{array}$ \\
\hline RCT, Sivapalan et al. [41] & $\begin{array}{l}\text { AECOPD } \\
\text { (admitted) }\end{array}$ & 318 & DAOH14 & $\begin{array}{l}\text { Reduced by 60\% } \\
\text { (no apparent risk) }\end{array}$ & Open-label & $\begin{array}{l}\text { Successful reduction of } \\
\text { corticosteroid exposure }\end{array}$ \\
\hline
\end{tabular}

AECOPD, acute exacerbated chronic obstructive pulmonary disease; DAOH14, days alive and out of hospital within 14 days from recruitment; PCT, procalcitonin; RCTs, randomized controlled trials.

"shift of pathway," from a "specific pathway" (where calcitonin precursors are released in secretory granules with enzyme activity to process the precursors to mature calcitonin hormone) to a more "generalized pathway" (where calcitonin precursors are "bulk released" without secretory granules and thus without enzymatic activity to process peptides) [45]. Other calcitonin precursors can be upregulated during bacterial infections and other acute diseases; of these the mid-region pro-adrenomedullin has been claimed to be a valuable severity marker in sepsis $[46,47]$.

\section{PCT in Diagnosis of COPD Exacerbation}

PCT is a biomarker of bacterial infection [48], which is released $2-6 \mathrm{~h}$ after IL- $1 \beta$ stimulation; however, it can be almost completely blocked by coadministration of IFN $\gamma$ [49], this suggesting a potential use in diagnosis and eventual applicability in differentiating between viral and bacterial acute exacerbated COPD (AECOPD). In a diagnostic accuracy study $(n=98)$ of patients with severe and very severe COPD exacerbation, a PCT of $<0.5 \mathrm{ng} / \mathrm{mL}$ was observed to have a negative predictive value of $95 \%$ for isolation of a human pathogenic bacterium from the airway culture [50]. This has, however, been disputed; and in another small study $(n=72)$, no difference in PCT was found between patients with viral and bacterial origin of COPD exacerbation. A meta-analysis in this area did though show a clear link between PCT and bacterial infections as the cause of COPD exacerbation, but states low quality of evidence. In conclusion, PCT is not a secure way to discriminate bacterial versus viral cause of COPD exacerbation. Instead, investigators have moved on to find out if PCT can predict which patients need antibiotics during a COPD exacerbation. The rationale for this is that many COPD patients can carry bacteria in the airways, without these causing the current exacerbation (i.e., "innocent bystander"), and further that some bacterial infections are mild and may not need antibiotics, since these also carry side effects. Additionally, it is well-documented that low PCT levels effectively rule out bacteremia $[51,52]$.

\section{PCT-Guided Antibiotic Treatment of AECOPD}

In 2004, Christ-Crain et al. [53] reported on a clusterRCT, in which an antibiotic-sparing strategy was tested. In general, patients with lower respiratory tract infections who had daily PCT measurements, had antibiotics discontinued, whenever the biomarker was below 0.25 $\mathrm{ng} / \mathrm{mL}$. This resulted in a noteworthy reduction in antibiotic use of approximately 50\% without any apparent cost on treatment effect. Looking at the subgroup of patients with COPD exacerbation, the effect seemed even higher. The main criticism of the trial was, that it was cluster randomized on institutional level, and thus, that patients were not randomized on an individual patient level. Several individual-level classic RCTs have subsequently confirmed the results of the initial study regarding antibiotic reduction in patients with lower respiratory tract infections, in settings as diverse as primary care [54], departments of respiratory medicine [55], internal medicine, emergency medicine [56], and intensive care [57]. Although results have been very consistent regarding COPD exacerbations (high effect, 50$70 \%$ reduction in antibiotics use), when analyzed in subgroups, only few RCTs exist, in which the entire population have been patients with COPD exacerbation. In one RCT $(n=120)$ [55], the length of antibiotic administration in COPD patients with hospitalization-requiring exacerbation, was reduced from 8.5 days to 3.5 days, $p<0.001$. Another trial included COPD patients with exacerbation, but did not report antibiotic use, rather re-exacerbation within 6 months, which did not seem 
Table 2. Reduction in antibiotics exposure in RCTs with PCT-controlled algorithms

\begin{tabular}{|c|c|c|c|c|c|c|}
\hline $\begin{array}{l}\text { Study type and } \\
\text { author }\end{array}$ & Patient group & $N$ & Primary outcome & $\begin{array}{l}\text { Reduction in antibiotic } \\
\text { exposure PCT arm } \\
\text { versus control }\end{array}$ & Strengths/weaknesses & Conclusion \\
\hline $\begin{array}{l}\text { Multicenter RCT, } \\
\text { Schuetz et al. [56] }\end{array}$ & $\begin{array}{l}\text { LRTI (emergency } \\
\text { departments) }\end{array}$ & 1,359 & $\rightarrow$ & $\begin{array}{l}\text { From } 8.7 \text { to } 5.7 \text { days } \\
\text { (no apparent risk) }\end{array}$ & $\begin{array}{l}\text { Heterogeneity in } \\
\text { population } \\
\text { (pneumonia, } \\
\text { AECOPD, and } \\
\text { bronchitis) }\end{array}$ & $\begin{array}{l}\text { Successful reduction of } \\
\text { antibiotics duration }\end{array}$ \\
\hline $\begin{array}{l}\text { RCT, Wang et al. } \\
\text { [59] }\end{array}$ & AECOPD & 194 & $\begin{array}{l}\text { Antibiotics no } \\
\text { better than placebo } \\
\text { for PCT }<0.1 \mathrm{ng} / \\
\mathrm{mL}\end{array}$ & $\begin{array}{l}100 \% \text { for patients with } \\
\text { PCT }<0.1 \mathrm{ng} / \mathrm{mL} \\
\text { (no apparent risk) }\end{array}$ & $\begin{array}{l}\text { Small } n \text {, did not look } \\
\text { at PCT effect (but } \\
\text { could report it) }\end{array}$ & $\begin{array}{l}\text { Successful reduction of } \\
\text { antibiotic exposure }\end{array}$ \\
\hline $\begin{array}{l}\text { Meta-analysis of } \\
\text { RCTs, Schuetz et } \\
\text { al. [60] }\end{array}$ & $\begin{array}{l}\text { Primary care, } \\
\text { emergency medicine, } \\
\text { respiratory medicine, } \\
\text { critically ill }\end{array}$ & 6,708 & All-cause mortality & $\begin{array}{l}2.7 \text { days reduction, } \\
p<0.0001\end{array}$ & $\begin{array}{l}\text { Not powered for all } \\
\text { effects in all } \\
\text { subgroups }\end{array}$ & $\begin{array}{l}\text { Lower mortality, fewer } \\
\text { antibiotic-related side } \\
\text { effects, and lower } \\
\text { consumption of } \\
\text { antibiotics }\end{array}$ \\
\hline
\end{tabular}

LRTI, lower respiratory tract infections; COPD, chronic obstructive pulmonary disease; ECOPD, exacerbated chronic obstructive pulmonary disease; AECOPD, acute exacerbated chronic obstructive pulmonary disease; ICU, intensive care unit; PCT, procalcitonin; RCTs, randomized controlled trials.

different in the randomized arms [58]. In a Chinese RCT, it was explored whether antibiotics improved the prognosis in patients with low $(<0.1 \mathrm{ng} / \mathrm{mL})$ PCT; the investigators did not observe any difference, but the use of antibiotics was reduced from 100\% (95 of 95 in the antibiotic group) to $17.7 \%$ (17 of 96 in the control group) based on the low PCT [59].

The results from PCT-guided antibiotic-sparing regimes in patients with lower respiratory tract infections have been summarized in a meta-analysis of 26 RCTs with 6,708 patients who were individually randomized. The main result was that 30-day all-cause mortality was reduced in PCT-guided patients (286 [9\%] of 3,336 PCTguided patients vs. 336 [10\%] in 3,372 controls; adjusted odds ratio 0.83 [95\% CI 0.70-0.99], $p=0.037$ ). Additionally, PCT guidance was associated with a 2.4 -day reduc- tion in antibiotic exposure (5.7 vs. 8.1 days [95\% CI -2.71 to -2.15 ], $p<0.0001$ ).

In conclusion, PCT guidance of antibiotic use in COPD patients with exacerbations is only examined directly in few and small trials. However, results from these trials are consistent with subgroup analysis from trials recruiting broader, but in which the COPD cohort could be analyzed separately. All these results regarding COPD exacerbations are also consistent with trial results from other patient groups with lower respiratory tract infections, so summarized, they seem solid, and consistently show a reduction in the use of unnecessary antibiotics in a magnitude of $50-70 \%$ of all administered antibiotics for these patients.

Such biomarker-guided strategies may prove key in reducing the antibiotic overuse, as summarized in a meta- 


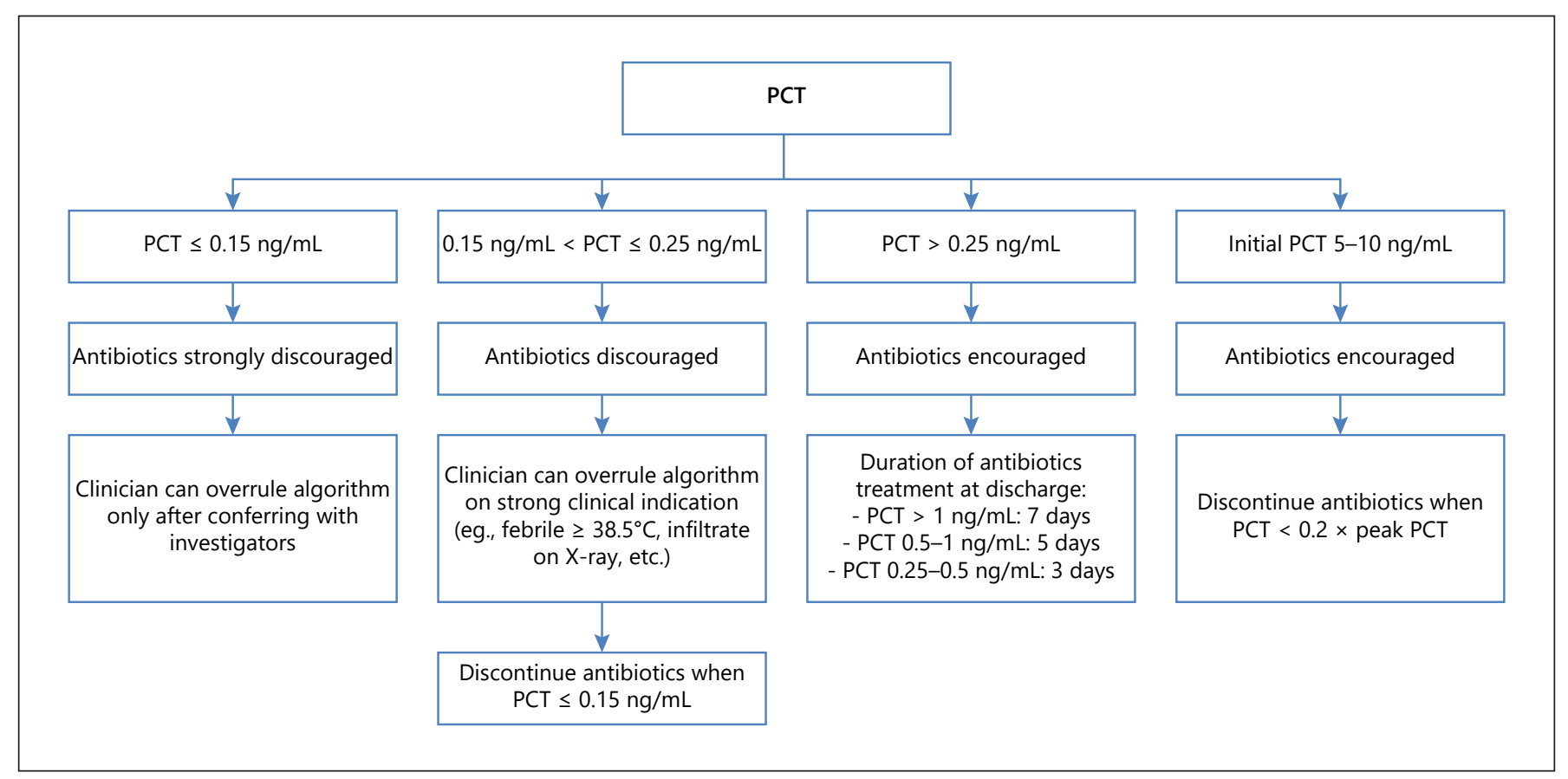

Fig. 3. PCT algorithm from [56]. PCT, procalcitonin.

analysis by Schuetz et al. [60], which is important when facing emerging antibiotic-resistant bacteria. See Table 2, in which some of the most important RCT results regarding PCT-guided antibiotic therapy are noted, including the main characteristics and results. Figure 3 shows a proposed algorithm for use when discontinuing antibiotics in COPD patients with exacerbations, as used in reference 55.

\section{Conclusion}

In conclusion, there is evidence at level $1 \mathrm{~B}$ (one RCT) to support the use of blood eosinophils in reducing the use of systemic corticosteroids in patients admitted to hospital with a severe AECOPD; a strategy which is noninferior regarding death and hospitalization length (days alive and out of hospital). Such a strategy seems applicable to implement in settings where a leukocyte differential count is available for daily analysis. Further, during admission of AECOPD, PCT measurements with approximately every $48 \mathrm{~h}$ can lead to a reduction in antibiotics of at least $30 \%$, without any obvious disadvantages; in fact, such a strategy reduces mortality and antibiotic-related side effects in patients with lower respiratory tract infections (level $1 \mathrm{~A}$ evidence), effects that seem likely also to apply to COPD patients.

Biomarkers to Reduce Side Effects in

Treatment of Lung Infections

\section{Acknowledgement}

We thank Mr. Valdemar Rømer for careful coordination and helping with the drafting of this manuscript.

\section{Conflict of Interest Statement}

The authors declare no conflicts of interest.

\section{Funding Sources}

P.S. was funded by the Danish Regions Medical Fund (grant no. 5894/16), the Danish Council for Independent Research (grant no. 6110-00268B), and Herlev-Gentofte University Hospital.

\section{Author Contributions}

Both authors contributed equally to the conception, design, and writing of the manuscript. 


\section{References}

1 Hopstaken RM, Muris JW, Knottnerus JA, Kester AD, Rinkens PE, Dinant GJ. Contributions of symptoms, signs, erythrocyte sedimentation rate, and C-reactive protein to a diagnosis of pneumonia in acute lower respiratory tract infection. Br J Gen Pract. 2003 May;53(490):358-64.

2 Cazzola M, Rogliani P, Aliberti S, Blasi F, Matera MG. An update on the pharmacotherapeutic management of lower respiratory tract infections. Expert Opin Pharmacother. 2017 Jul;18(10):973-88.

3 Neuville M, Vinclair C, Cally R, Bouadma L. [Place of biomarkers in the management of pulmonary infections]. Rev Mal Respir. 2019 Mar;36(3):405-14.

4 Gan WQ, Man SF, Senthilselvan A, Sin DD. Association between chronic obstructive pulmonary disease and systemic inflammation: a systematic review and a meta-analysis. Thorax. 2004 Jul;59(7):574-80.

5 van de Geijn GM, Denker S, Meuleman-van Waning V, Koeleman HG, Birnie E, Braunstahl GJ, et al. Evaluation of new laboratory tests to discriminate bacterial from nonbacterial chronic obstructive pulmonary disease exacerbations. Int J Lab Hematol. 2016 Dec; 38(6):616-28

6 Mathioudakis AG, Janssens W, Sivapalan P, Singanayagam A, Dransfield MT, Jensen JS, et al. Acute exacerbations of chronic obstructive pulmonary disease: in search of diagnostic biomarkers and treatable traits. Thorax. 2020 Jun;75(6):520-7.

7 Singh D, Kolsum U, Brightling CE, Locantore N, Agusti A, Tal-Singer R, et al. Eosinophilic inflammation in COPD: prevalence and clinical characteristics. Eur Respir J. 2014 Dec; 44(6):1697-700.

8 Tashkin DP, Wechsler ME. Role of eosinophils in airway inflammation of chronic obstructive pulmonary disease. Int J Chron Obstruct Pulmon Dis. 2018;13:335-49.

9 Farne HA, Wilson A, Powell C, Bax L, Milan SJ. Anti-IL5 therapies for asthma. Cochrane Database Syst Rev. 2017 Sep 21;9:CD010834.

10 Criner GJ, Celli BR, Brightling CE, Agusti A, Papi A, Singh D, et al. Benralizumab for the Prevention of COPD Exacerbations. N Engl J Med. 2019 Sep 12;381(11):1023-34.

11 Decramer M, Janssens W, Miravitlles M. Chronic obstructive pulmonary disease. Lancet. 2012 Apr 7;379(9823):1341-51.

12 Barnes PJ, Burney PG, Silverman EK, Celli BR, Vestbo J, Wedzicha JA, et al. Chronic obstructive pulmonary disease. Nat Rev Dis Primers. 2015 Dec 3;1:15076.

13 Siafakas N, Corlateanu A, Fouka E. Phenotyping Before Starting Treatment in COPD?.COPD. 2017 Jun;14(3):367-74.

14 Barnes PJ. Inflammatory endotypes in COPD. Allergy. 2019 Mar 4;74:1249-56.

15 Pascoe S, Locantore N, Dransfield MT, Barnes NC, Pavord ID. Blood eosinophil counts, exacerbations, and response to the addition of inhaled fluticasone furoate to vilanterol in patients with chronic obstructive pulmonary disease: a secondary analysis of data from two parallel randomised controlled trials. Lancet Respir Med. 2015 Jun;3(6):435-42.

16 Vedel-Krogh S, Nielsen SF, Lange P, Vestbo J, Nordestgaard BG. Blood eosinophils and exacerbations in chronic obstructive pulmonary disease. The copenhagen general population study. Am J Respir Crit Care Med. 2016 May 1;193(9):965-74.

17 Couillard S, Larivée P, Courteau J, Vanasse A. Eosinophils in COPD exacerbations are associated with increased readmissions. Chest. 2017 Feb;151(2):366-73.

18 Russell REK, Bafadhel M. Investigating blood eosinophil count thresholds in patients with COPD. Lancet Respir Med. 2018 Nov;6(11): 823-4.

19 Yun JH, Lamb A, Chase R, Singh D, Parker MM, Saferali A, et al. Blood eosinophil count thresholds and exacerbations in patients with chronic obstructive pulmonary disease. J Allergy Clin Immunol. 2018 Jun;141(6):203747.e10.

20 Zeiger RS, Tran TN, Butler RK, Schatz M, Li Q, Khatry DB, et al. Relationship of blood eosinophil count to exacerbations in chronic obstructive pulmonary disease. J Allergy Clin Immunol Pract. 2018 May-Jun;6(3):944-54. e5.

21 Vogelmeier CF, Criner GJ, Martinez FJ, Anzueto A, Barnes PJ, Bourbeau J, et al. Global strategy for the diagnosis, management, and prevention of chronic obstructive lung disease 2017 report. GOLD executive summary. Am J Respir Crit Care Med. 2017 Mar 1; 195(5):557-82.

22 Saeed MI, Eklöf J, Achir I, Sivapalan P, Meteran H, Løkke A, et al. Use of inhaled corticosteroids and the risk of developing type 2 diabetes in patients with chronic obstructive pulmonary disease. Diabetes Obes Metab. 2020 Aug;22(8):1348-56.

23 Nadeem NJ, Taylor SJ, Eldridge SM. Withdrawal of inhaled corticosteroids in individuals with COPD-a systematic review and comment on trial methodology. Respir Res. 2011 Aug 12;12:107.

24 Matera MG, Cardaci V, Cazzola M, Rogliani P. Safety of inhaled corticosteroids for treating chronic obstructive pulmonary disease. Expert Opin Drug Saf. 2015 Apr;14(4):53341.

25 Siva R, Green RH, Brightling CE, Shelley M, Hargadon B, McKenna S, et al. Eosinophilic airway inflammation and exacerbations of COPD: a randomised controlled trial. Eur Respir J. 2007 May;29(5):906-13.

26 Siddiqui SH, Guasconi A, Vestbo J, Jones P, Agusti A, Paggiaro P, et al. Blood eosinophils: a biomarker of response to extrafine beclomethasone/formoterol in chronic obstructive pulmonary disease. Am J Respir Crit Care Med. 2015 Aug 15;192(4):523-5.
27 Bafadhel M, Peterson S, De Blas MA, Calverley PM, Rennard SI, Richter K, et al. Predictors of exacerbation risk and response to budesonide in patients with chronic obstructive pulmonary disease: a post-hoc analysis of three randomised trials. Lancet Respir Med. 2018 Feb;6(2):117-26.

28 Watz H, Tetzlaff K, Wouters EF, Kirsten A, Magnussen H, Rodriguez-Roisin R, et al. Blood eosinophil count and exacerbations in severe chronic obstructive pulmonary disease after withdrawal of inhaled corticosteroids: a post-hoc analysis of the WISDOM trial. Lancet Respir Med. 2016 May;4(5):390-8.

29 Lipson DA, Barnhart F, Brealey N, Brooks J, Criner GJ, Day NC, et al. Once-daily singleinhaler triple versus dual therapy in patients with COPD. N Engl J Med. 2018 May 3; 378(18):1671-80.

30 Papi A, Vestbo J, Fabbri L, Corradi M, Prunier H, Cohuet G, et al. Extrafine inhaled triple therapy versus dual bronchodilator therapy in chronic obstructive pulmonary disease (TRIBUTE): a double-blind, parallel group, randomised controlled trial. Lancet. 2018 Mar 17;391(10125):1076-84.

31 Singh D, Agusti A, Anzueto A, Barnes PJ, Bourbeau J, Celli BR, et al. Global strategy for the diagnosis, management, and prevention of chronic obstructive lung disease: the GOLD science committee report 2019. Eur Respir J. 2019 May;53(5):1900164.

32 Chalmers JD, Laska IF, Franssen FME, Janssens W, Pavord I, Rigau D, et al. Withdrawal of inhaled corticosteroids in COPD: a European Respiratory Society guideline. Eur Respir J. 2020 Jun;55(6):2000351.

33 Walters JA, Tan DJ, White CJ, Gibson PG Wood-Baker R, Walters EH. Systemic corticosteroids for acute exacerbations of chronic obstructive pulmonary disease. Cochrane Database Syst Rev. 2014 Sep 1(9):CD001288.

34 Sivapalan P, Ingebrigtsen TS, Rasmussen DB, Sørensen R, Rasmussen CM, Jensen CB, et al. COPD exacerbations: the impact of long versus short courses of oral corticosteroids on mortality and pneumonia: nationwide data on 67000 patients with COPD followed for 12 months. BMJ Open Respir Res. 2019;6(1):e000407.

35 Walsh LJ, Wong CA, Oborne J, Cooper S, Lewis SA, Pringle M, et al. Adverse effects of oral corticosteroids in relation to dose in patients with lung disease. Thorax. 2001 Apr; 56(4):279-84.

36 Waljee AK, Rogers MA, Lin P, Singal AG, Stein JD, Marks RM, et al. Short term use of oral corticosteroids and related harms among adults in the United States: population based cohort study. Bmj. 2017 Apr 12;357:j1415.

37 Bafadhel M, McKenna S, Terry S, Mistry V, Pancholi M, Venge P, et al. Blood eosinophils to direct corticosteroid treatment of exacerbations of chronic obstructive pulmonary disease: a randomized placebo-controlled trial. Am J Respir Crit Care Med. 2012 Jul 1;186(1):48-55. 
38 Duman D, Aksoy E, Agca MC, Kocak ND, Ozmen I, Akturk UA, et al. The utility of inflammatory markers to predict readmissions and mortality in COPD cases with or without eosinophilia. Int J Chron Obstruct Pulmon Dis. 2015;10:2469-78.

39 Bafadhel M, Greening NJ, Harvey-Dunstan TC, Williams JE, Morgan MD, Brightling CE, et al. Blood eosinophils and outcomes in severe hospitalized exacerbations of COPD. Chest. 2016 Aug;150(2):320-8.

40 Serafino-Agrusa L, Scichilone N, Spatafora M, Battaglia S. Blood eosinophils and treatment response in hospitalized exacerbations of chronic obstructive pulmonary disease: a case-control study. Pulm Pharmacol Ther. 2016 Apr;37:89-94.

41 Sivapalan P, Lapperre TS, Janner J, Laub RR, Moberg M, Bech CS, et al. Eosinophil-guided corticosteroid therapy in patients admitted to hospital with COPD exacerbation (CORTICO-COP): a multicentre, randomised, controlled, open-label, non-inferiority trial. Lancet Respir Med. 2019 Aug;7(8):699-709.

42 Weglohner W, Struck J, Fischer-Schulz C, Morgenthaler NG, Otto A, Bohuon C, et al. Isolation and characterization of serum procalcitonin from patients with sepsis. Peptides. 2001 Dec;22(12):2099-103.

43 Birnbaum RS, Mahoney WC, Burns DM, O’Neil JA, Miller RE, Roos BA. Identification of procalcitonin in a rat medullary thyroid carcinoma cell line. J Biol Chem. 1984 Mar 10; 259(5):2870-4.

44 Muller B, White JC, Nylen ES, Snider RH, Becker KL, Habener JF. Ubiquitous expression of the calcitonin-i gene in multiple tissues in response to sepsis. J Clin Endocrinol Metab. 2001 Jan;86(1):396-404.

45 Becker KL, Nylén ES, White JC, Müller B, Snider RH Jr. Clinical review 167: procalcitonin and the calcitonin gene family of peptides in inflammation, infection, and sepsis: a journey from calcitonin back to its precursors. J Clin Endocrinol Metab. 2004 Apr;89(4) 1512-25.
46 Christ-Crain M, Morgenthaler NG, Struck J, Harbarth S, Bergmann A, Müller B. Mid-regional pro-adrenomedullin as a prognostic marker in sepsis: an observational study. Crit Care. 2005;9(6):R816-24.

47 Christ-Crain M, Morgenthaler NG, Stolz D, Müller C, Bingisser R, Harbarth S, et al. Proadrenomedullin to predict severity and outcome in community-acquired pneumonia [ISRCTN04176397]. Crit Care. 2006;10(3): R96.

48 Assicot M, Gendrel D, Carsin H, Raymond J, Guilbaud J, Bohuon C. High serum procalcitonin concentrations in patients with sepsis and infection. Lancet. 1993 Feb 27;341(8844): 515-8.

49 Linscheid P, Seboek D, Nylen ES, Langer I, Schlatter M, Becker KL, et al. In vitro and in vivo calcitonin I gene expression in parenchymal cells: a novel product of human adipose tissue. Endocrinology. 2003 Dec; 144(12): 5578-84.

50 Nseir S, Cavestri B, Di Pompeo C, Diarra M, Brisson $\mathrm{H}$, Lemyze $\mathrm{M}$, et al. Factors predicting bacterial involvement in severe acute exacerbations of chronic obstructive pulmonary disease. Respiration. 2008;76(3):253-60.

51 Chirouze C, Schuhmacher H, Rabaud C, Gil $\mathrm{H}$, Khayat N, Estavoyer JM, et al. Low serum procalcitonin level accurately predicts the $\mathrm{ab}$ sence of bacteremia in adult patients with acute fever. Clin Infect Dis. 2002 Jul 15;35(2): 156-61.

52 Gaini S, Koldkjaer OG, Moller HJ, Pedersen C, Pedersen SS. A comparison of high-mobility group-box 1 protein, lipopolysaccharidebinding protein and procalcitonin in severe community-acquired infections and bacteraemia: a prospective study. Crit Care. 2007; 11(4):R76.

53 Christ-Crain M, Jaccard-Stolz D, Bingisser R, Gencay MM, Huber PR, Tamm M, et al. Effect of procalcitonin-guided treatment on antibiotic use and outcome in lower respiratory tract infections: cluster-randomised, singleblinded intervention trial. Lancet. $2004 \mathrm{Feb}$ 21;363(9409):600-7.
54 Briel M, Christ-Crain M, Young J, Schuetz P, Huber P, Périat $P$, et al. Procalcitonin-guided antibiotic use versus a standard approach for acute respiratory tract infections in primary care: study protocol for a randomised controlled trial and baseline characteristics of participating general practitioners [ISRCTN73182671]. BMC Fam Pract. 2005 Aug $18 ; 6: 34$

55 Corti C, Fally M, Fabricius-Bjerre A, Mortensen K, Jensen BN, Andreassen HF, et al. Point-of-care procalcitonin test to reduce antibiotic exposure in patients hospitalized with acute exacerbation of COPD. Int J Chron Obstruct Pulmon Dis. 2016;11:1381-9.

56 Schuetz P, Christ-Crain M, Thomann R, Falconnier C, Wolbers M, Widmer I, et al. Effect of procalcitonin-based guidelines vs standard guidelines on antibiotic use in lower respiratory tract infections: the ProHOSP randomized controlled trial. JAMA. 2009 Sep 9; 302(10):1059-66.

57 de Jong E, van Oers JA, Beishuizen A, Vos P, Vermeijden WJ, Haas LE, et al. Efficacy and safety of procalcitonin guidance in reducing the duration of antibiotic treatment in critically ill patients: a randomised, controlled, open-label trial. Lancet Infect Dis. 2016 Jul; 16(7):819-27.

58 Verduri A, Luppi F, D’Amico R, Balduzzi S, Vicini R, Liverani A, et al. Antibiotic treatment of severe exacerbations of chronic obstructive pulmonary disease with procalcitonin: a randomized noninferiority trial. PLoS One. 2015;10(3):e0118241

59 Wang JX, Zhang SM, Li XH, Zhang Y, Xu ZY, Cao B. Acute exacerbations of chronic obstructive pulmonary disease with low serum procalcitonin values do not benefit from antibiotic treatment: a prospective randomized controlled trial. Int J Infect Dis. $2016 \mathrm{Jul} ; 48: 40-5$.

60 Schuetz P, Wirz Y, Sager R, Christ-Crain M, Stolz D, Tamm M, et al. Effect of procalcitonin-guided antibiotic treatment on mortality in acute respiratory infections: a patient level meta-analysis. Lancet Infect Dis. 2018 Jan; 18(1):95-107. 